\title{
Irrigation and Fertilizer Management on Growth, Yield, Water and Fertilizer Use Efficiencies on Cabbage in a Sandy Loam Soil
}

\author{
Souptik Sarkar ${ }^{1 *}$, Rounak Saha $^{2}$ and Sanmay Kumar Patra ${ }^{1}$ \\ ${ }^{1}$ Department of Agricultural Chemistry and Soil Science, ${ }^{2}$ Department of Agricultural \\ Chemicals, Bidhan Chandra Krishi Viswavidyalaya, Mohanpur 741252, West Bengal, India \\ *Corresponding author
}

\begin{abstract}
A B S T R A C T
Keywords

Gravity drip irrigation, Head yield, Water use efficiency, Fertilizer use efficiency, Cabbage

Article Info

Accepted:

04 November 2020

Available Online:

10 December 2020

A field experiment comprising of four irrigation levels (drip irrigation at $0.6,0.80$ and 1.0 of $\mathrm{ET}_{0}$ and surface irrigation) and three fertilizer levels (125, 100 and $75 \%$ of RDF) was conducted during rabi season of 2019-2020 in a sandy loam soil on cabbage. The results showed that drip irrigation at $1.0 \mathrm{ET}_{0}$ with $125 \% \mathrm{RDF}$ registered the tallest plant (18.96 $\mathrm{cm})$, highest number of leaves (15.63), leaf area per plant $\left(3052.67 \mathrm{~cm}^{2}\right)$, LAI (2.04), diameter of head $(13.45 \mathrm{~cm})$, fresh weight of head $(980.21 \mathrm{~g})$ and maximum head yield (586.34 q/ha) which was competitive with drip irrigation at $1.0 \mathrm{ET}_{0}$ with $100 \% \mathrm{RDF}$ and drip irrigation at $0.8 \mathrm{ET}_{0}$ with 125 and $100 \% \mathrm{RDF}$. Lowest growth, yield components and yield were recorded in surface irrigation with $75 \%$ RDF. Maximum CWUE and FUE was found with drip irrigation at $0.6 \mathrm{ET}_{0}$ with $125 \%$ RDF. Drip irrigation levels saved 64.8$41.3 \%$ water as compared with surface irrigation which could bring another 77.3-43.0\% area under drip irrigation. Highest yield of 55.9 t/ha was predicted with ETa at $128 \mathrm{~mm}$ and irrigation at $73 \mathrm{~mm}$. Ky was estimated as $2.245\left(\mathrm{R}^{2}=0.84\right)$. Based on higher yield, CWUE, FUE and water saving, drip irrigation at $0.8 \mathrm{ET}_{0}$ with $100 \% \mathrm{RDF}$ was found to be the best treatment combination which may be advocated to the farmers of the IndoGangetic plains.
\end{abstract}

\section{Introduction}

Cabbage (Brassica oleracea L. var. capitata) is one of the most popular winter season leafy vegetables belonging to the member of Brassicaceae family. It is the second most important crop after cauliflower and native to South and Western part of Europe. It occupies prime place among cole crops due to its delicious taste, flavour and nutritive value. It is used as fresh salad, boiled vegetable and dehydrated vegetable as well as in cooked curries and pickles. The crop is well known for its medicinal properties and widely used for cough, fever, diarrhoea, peptic ulcers and skin diseases. It has anticancer property due to the presence of indole-3-carbinol. It is rich in carbohydrate, essential minerals and vitamins $\mathrm{A}, \mathrm{B} 1, \mathrm{~B} 2$ and $\mathrm{C}$ and contains good amount of a-carotene and dietary fiber and a small amount of protein with good caloric value (Nikzad et al., 2020; Hasan et al., 2018). India is the second largest cabbage producing countries after China. In India, 
cabbage is grown in an area of 0.40 million hectare covering $4 \%$ of the total vegetable area with an annual production of 9.04 million metric tonnes with an average productivity of $22.65 \mathrm{t} / \mathrm{ha}$ (Anon., 2019). The major cabbage cultivating Indian states are Uttar Pradesh, Madhya Pradesh, Odisha, Bihar, Assam, Gujarat, West Bengal, Maharashtra and Karnataka. It is grown an area of 74100 ha with production of 2.29 million metric tonnes and productivity of 27.6 t/ha in West Bengal.

Water constraint is one of the major environmental factors which adversely affect the plant (Shamshiri et al., 2011). The excessive irrigation has harmful effects on crop productivity, while inadequate irrigation in any physiological stage causes soil water stress and markedly reduces yield (Aiyelaagbe and Ogbonnaya, 1996). Under limited water availability, controlled irrigation scheduling matching with plant water requirement is considered an appropriate irrigation management strategy to ensure optimum soil moisture in root zone proximity for sustaining the yield and quality of produce with higher water use efficiency (Panigrahi et al., 2011; Himanshu et al., 2013). The meteorological based irrigation scheduling approach such as pan evaporation replenishment, cumulative pan evaporation, ratio between irrigation water and cumulative pan evaporation and soil moisture depletion have been used worldwide (Kumar and Senseba, 2008). However, drip irrigation has now become the most efficient and economically viable modern irrigation method where precise amount of water and nutrients in synchrony of crop demand is directly supplied in the effective root zone of each plant (Pattanaik et al., 2003; Nalliah et al., 2009; Rajurkar et al., 2012). In can reduce runoff loss, surface evaporation and minimal deep percolation of water and stress on plant and maintains a uniform distribution of water and nutrients around the rhizosphere (Postel et al., 2001; Brahma et al., 2010). This innovative irrigation technique helped in increasing yield with less amount of water applied (Gorantiwar et al., 1991).

Plant nutrition is another important factor for influencing adequate growth, development and quality in vegetable production (Indrea et al., 2014). Cabbage is a shallow rooted high yielding crop and a heavy feeder of nutrient and highly responsive to large dose of fertilizer application (Nikzad et al., 2020). It requires a proper and balanced supply of plant nutrients for profitable yield which can be mitigated by applying inorganic fertilizer or organic manure or both. The mineral fertilizers are becoming costlier day by day. Judicious management of fertilizer nutrients is thus prerequisite to use this input very cautiously and economically (Chaudhary et al., 2015). Higher fertilizer efficiency is possible with pressurized irrigation system along with soil fertilization or through drip fertigation (Kumar and Sahu, 2013).

In the Indo-Gangetic plains of West Bengal, cabbage is a commercial and profitable vegetable crop. The farmers generally follow the conventional surface method of irrigation with improper nutrition, which causes adverse effects of cyclic over irrigation and water stress on crop resulting in poor water and nutrient use efficiencies and depressed yield.

The state occupies the leading position in cabbage production, but the technical information on the irrigation schedule and nutritional aspect of the crop for higher yield is limited. Low cost gravity fed drip irrigation system is suitable for small land holding provided with user friendly accessories that enable small farmers to cultivate crop and can earn higher profit. Considering all these bottlenecks, the present experiment is designed with the objectives of optimizing 
drip irrigation schedule and fertilizer management for improving crop and water productivity, water and fertilizer use efficiencies of cabbage plant under field condition.

\section{Materials and Methods}

\section{Description of study area}

The field experiment was carried out during rabi season of 2019-20 on cabbage at Central Research Farm, Regional Research station, Bidhan Chandra Krishi Viswavidyalaya, Gayeshpur, Nadia belonging to Indo-Gangetic plains of West Bengal. The experimental site lies between $22^{0} 588^{\prime} 31^{\prime \prime} \mathrm{N}$ latitude and $88^{0} 26^{\prime} 20^{\prime \prime}$ E longitude with an altitude of 9.75 $\mathrm{m}$ above amsl. The climate is subtropicalsubhumid. The mean monthly temperature ranges between $37.6{ }^{\circ} \mathrm{C}$ to $25.4{ }^{\circ} \mathrm{C}$ in summer and $23.7{ }^{\circ} \mathrm{C}$ to $10.5{ }^{\circ} \mathrm{C}$ in winter.

The annual rainfall is about $1500 \mathrm{~mm}$, of which $75 \%$ is received during June through September. The mean relative humidity remains $82-95 \%$ in June-October and $70 \%$ in January. The wind speed velocity varies from 0.2 to $3.69 \mathrm{kmph}$. The pan evaporation loss ranges from 0.9-1.4 $\mathrm{mm} /$ day during December-January and 4.2 to $4.6 \mathrm{~mm}$ /day during April-May. The depth of groundwater table ranges from 3.8 to $6.5 \mathrm{~m} \mathrm{bgl}$.

The mean monthly meteorological data during the experimental period is presented in Table 1. The soil was sandy loam in texture (Typic Fluvaquept) with sand $70.2 \%$, silt $15.7 \%$ and clay $14.1 \%$ having bulk density $1.49 \mathrm{Mg} / \mathrm{m}^{3}$, hydraulic conductivity $22.8 \mathrm{~mm} / \mathrm{hr}, \mathrm{FC}$ 52.37\%, PWP 15.64\%, pH 6.9, EC 0.25 dS/m, CEC $15.6 \mathrm{cmol} / \mathrm{kg}$ and organic C $5.2 \mathrm{~g} / \mathrm{kg}$. The soil was low in available $\mathrm{N}(168.7 \mathrm{~kg} / \mathrm{ha})$ and medium in available $\mathrm{P}(35.6 \mathrm{~kg} / \mathrm{ha})$ and available K (151.5 kg/ha).

\section{Experimental treatments and design}

The experiment consisted of twelve treatment combinations with four irrigation levels (gravity drip irrigation schedule at 1.0, 0.8 and 0.6 of pan evaporation replenishment, $\mathrm{ET}_{0}$ and surface irrigation) allotted in main plots and three graded levels of fertilizer (125, 100 and $75 \%$ of recommended dose of fertilizer) assigned in sub-plots was laid out in a split plot design with three replications.

\section{Agronomic manipulations}

The field area of $42.5 \mathrm{~m} \times 14.0 \mathrm{~m}$ was partitioned into three equal blocks. Each block was further divided into 12 plots where 12 treatment combinations were distributed at random. The net plot size was $2.4 \mathrm{~m} \times 2.5 \mathrm{~m}$ leaving $0.5 \mathrm{~m}$ bund width and $1.0 \mathrm{~m}$ irrigation channel. The healthy 30 day old seedlings of cabbage cultivar Green Ball was transplanted at a spacing of $50 \mathrm{~cm} \times 30 \mathrm{~cm}$ on 26 December 2019. FYM containing $0.5 \% \mathrm{~N}$, $0.3 \% \mathrm{P}_{2} \mathrm{O}_{5}$ and $0.5 \% \mathrm{~K}_{2} \mathrm{O}$ on dry weight basis @ $15 \mathrm{t} /$ ha was uniformly applied to each plot and thoroughly mixed with the soil during final land preparation. As per treatment schedules, 125,100 and $75 \%$ of RDF $\left(\mathrm{N}: \mathrm{P}_{2} \mathrm{O}_{5}: \mathrm{K}_{2} \mathrm{O}:: 150: 80: 75 \mathrm{~kg} / \mathrm{ha}\right)$ were applied in the form of urea, single superphosphate and muriate of potash, respectively. One half dose of $\mathrm{N}$ and full dose of $\mathrm{P}$ and $\mathrm{K}$ were applied at the time of transplanting and the remaining half dose of $\mathrm{N}$ was top dressed at 30 and 60 days after planting. The crop was harvested within 28 March 2020. The growing period was lasted for 94 days. The necessary cultural operations like gap filling, weeding, earthing up and standard plant protection measures were equally performed in all the treatments. Five plants from the inner rows of unit plot from each treatment and replication were tagged for recording the growth, yield components and yield data. 


\section{Irrigation schedules}

Conventional practice of surface irrigation was applied at $40 \mathrm{~mm}$ depth at 20 days interval whereas drip irrigation was scheduled at $1.0,0.8$ and 0.6 of $\mathrm{ET}_{0}$ at 2 days interval. Three irrigations were used in surface irrigation while 19 irrigations were employed for gravity fed drip irrigation.

\section{Estimation of drip irrigation water requirement}

The amount of water applied by gravity drip irrigation system was calculated based on $\mathrm{ET}_{0}$ using the equation as, $\mathrm{I}=\mathrm{E}_{\mathrm{p}} \times \mathrm{K}_{\mathrm{p}} \times \mathrm{K}_{\mathrm{c}} \times \mathrm{W}_{\mathrm{P}}$

Where, I is the irrigation water $(\mathrm{mm}), \mathrm{E}_{\mathrm{p}}$ is the open pan evaporation (mm), $K_{p}$ is the pan coefficient, $K_{c}$ is the crop coefficient and $W_{P}$ is the percentage of wetted area. $\mathrm{W}_{\mathrm{P}}$ was taken as $100 \%$ considering that lateral interval was equal to the spaces between the drippers. $\mathrm{K}_{\mathrm{p}}$ value was taken as $0.75 . \mathrm{K}_{\mathrm{c}}$ values adopted for development, mid and late season stages of the plant was 0.70, 1.05 and 0.95, respectively (Allen et al., 1998). Daily evaporation data was recorded from a standard US Weather Bureau Class A Pan installed inside the experimental site on a wooden support at a height of $15 \mathrm{~cm}$ above the soil surface. Surface irrigation water was discharged from shallow tube well connected with suitable valves arrangement and was measured by Parshall flume. In gravity fed drip irrigation, groundwater was pumped put from a deep tubewell to a $500 \mathrm{~L}$ capacity over head tank installed at a height of $3.3 \mathrm{~m}$ above the ground level. Two drippers per plant were provided on either side of plant at a distance of $30 \mathrm{~cm}$. The discharge rate of each dripper/emitter in gravity drip system was 1.8 lph with an operating pressure of $0.65 \mathrm{~kg} / \mathrm{cm}^{2}$. The laterals (12 mm diameter) were arranged in such a way that every row had two laterals with $30 \mathrm{~cm}$ intervals. Groundwater quality was good (EC $0.36 \mathrm{dS} \mathrm{m}^{-1}$ ) and safely used for irrigation.

\section{Estimation of crop water requirement}

Seasonal crop water use or actual crop evapotranspiration (ETa) for cabbage under the different irrigation treatments during the entire cropping period was computed using the following one-dimensional water balance equation (Simsek et al., 2005):

$\mathrm{ETa}=\mathrm{I}+\mathrm{Re}+\mathrm{Cp}-\mathrm{Rf} \pm \Delta \mathrm{S}$

Where, ETa is the seasonal actual crop evapotranspiration $(\mathrm{mm})$, I is the irrigation water applied $(\mathrm{mm}), \mathrm{R}_{\mathrm{e}}$ is the effective rainfall, $C_{p}$ is the contribution through capillary rise from groundwater $(\mathrm{mm}), \mathrm{Rf}$ is the surface runoff $(\mathrm{mm})$ and $\pm \Delta S$ is the change in soil water storage in the profile between planting and harvest time $(\mathrm{mm})$ in the $0-45 \mathrm{~cm}$ layer. Re was calculated by field soil moisture balance method (FAO, 1974). Cp was assumed to be negligible as depth of groundwater was more than $4.5 \mathrm{~m}$ below ground surface. $\mathrm{Rf}$ was eliminated by providing suitable bund at $50 \mathrm{~cm}$ height around the unit plot and controlled water application through drip and surface irrigation system. Thus, the ETa $=\mathrm{I}+\mathrm{R}_{\mathrm{e}} \pm \Delta \mathrm{S}$. The estimated monthly and daily consumptive use of water in cabbage is given in Table 2 .

\section{Crop water use efficiency}

The crop water use efficiency (CWUE) was calculated as the ratio of head yield (Y) to total crop water use (ETa) as proposed by Howell et al., (2000):

$\mathrm{CWUE}=\mathrm{Y} / \mathrm{ETa}(\mathrm{kg} / \mathrm{ha}-\mathrm{mm})$

where, $\mathrm{Y}=$ Fresh head yield $(\mathrm{kg} / \mathrm{ha})$ and ETa $=$ actual crop evapotranspiration $(\mathrm{mm})$ 


\section{Computation of additional cultivated area}

The additional cultivated area (X) i.e. the area that could be cultivated by utilizing the water saved from drip irrigation was calculated by the equation:

$$
X=\frac{\text { Water saved from drip irrigation }}{\text { Total water used for drip irrigation }} \times 100
$$

\section{Yield response factor}

The response of yield to water use is quantified through the yield response factor (Ky) and was computed by the Stewart's model (Stewart et al., 1977).

\section{Fertilizer use efficiency}

The fertilizer use efficiency (FUE) was computed by the following equation:

$$
\text { FUE }=\frac{\text { Fresh head yield }(\mathrm{kg} / \mathrm{ha})}{\text { Total quantity of nutrient applied }(\mathrm{kg} / \mathrm{ha})}
$$

\section{Statistical analysis}

The data generated for different plant parameters were subjected to analysis of variance techniques appropriate to split plot design using software packages of MS Excel and SPSS 16.0 version. Statistical significance between means of individual treatments was assessed using Fisher's least significant difference (LSD) at $p<0.05$ (Gomez and Gomez, 1984).

\section{Results and Discussion}

\section{Growth, yield components and yield}

The growth, yield components and yield of cabbage were significantly affected by individual or combined effect of irrigation and fertilization levels (Table 3). The tallest plant $(18.17 \mathrm{~cm})$, highest number of leaves
(15.34), leaf area per plant $\left(3031.32 \mathrm{~cm}^{2}\right)$, LAI (2.02), diameter of head $(13.22 \mathrm{~cm})$, fresh weight of head (951.66 g) and highest head yield $(556.78 \mathrm{q} / \mathrm{ha})$ were obtained with drip irrigation at $1.0 \quad \mathrm{ET}_{0}\left(\mathrm{I}_{1}\right)$ which was statistically at par with drip irrigation at 0.8 $\mathrm{ET}_{0}\left(\mathrm{I}_{2}\right)$ with the corresponding value of $17.98 \mathrm{~cm}, 15.17,3016.43 \mathrm{~cm}^{2}, 2.01,13.12$ $\mathrm{cm}, 937.1 \mathrm{~g}$ and $546.21 \mathrm{q} / \mathrm{ha}$, respectively. Both treatments were superior to that with drip irrigation at $0.6 \mathrm{ET}_{0}\left(\mathrm{I}_{3}\right)$ and surface irrigation $\left(\mathrm{I}_{4}\right)$. Significantly the shortest plant height $(15.97 \mathrm{~cm})$, lowest number of leaves (14.25), leaf area per plant $\left(2852.48 \mathrm{~cm}^{2}\right.$, LAI (1.90), diameter of head $(12.39 \mathrm{~cm})$, fresh weight of head $(770.07 \mathrm{~g})$ and head yield (440.9 q/ ha) was recorded with surface irrigation $\left(\mathrm{I}_{4}\right)$. The improvement in growth, yield components and head yield under higher level of irrigation applied through drip irrigation system might be ascribed to the sustenance of optimum moisture availability in the vicinity of root zone across the plant stages and better water utilization, thereby eliminating the soil water stress and the turgid pressure of plant cells which in turn increased the vegetative growth parameters like plant height, number of leaves, leaf area and LAI (Kumar et al., 2007; Himanshu et al., (2012). The higher leaf area may result in greater photosynthetic area in response to increased moisture availability leading to faster carbohydrate production by photosynthesis and efficient translocation of photosynthates towards the reproductive organ i.e., head that helps increase the size and weight of head and finally enhanced the total head yield (Agrawal et al., 2018). The lower head yield in surface irrigation might be due to less availability of water to plant in some growth stages even though the applied irrigation water was too high. The excess moisture tends to leach down the nutrients beyond the root zone reflecting in depressed the growth, yield constituents and yield. The shortest plant characters and decline in yield under higher 
deficit drip irrigation regime at $0.6 \mathrm{ET}_{0}$ might be due to high soil water stress which failed to fulfil the crop water requirement, thereby restricting the transpiration, stomatal opening, reduced ${ }^{14} \mathrm{CO}_{2}$ fixation and nutrients absorption, low rate of photosynthesis and other biochemical reactions leading to depressed plant attributes and yield (Vaux and Pruitt, 1983). The superiority of drip irrigation at higher level on rabi cabbage production was reported earlier by Kumar and Sahu (2013).

As regards to fertilizer management, addition of $125 \% \mathrm{RDF}\left(\mathrm{F}_{1}\right)$ recorded the highest plant height $(18.01 \mathrm{~cm})$, number of leaves $(15.14)$, leaf area per plant $\left(2998.28 \mathrm{~cm}^{2}\right)$, LAI (2.00), diameter of head $(13.07 \mathrm{~cm})$, fresh weight of head $(889.63 \mathrm{~g})$ and head yield (537.27 q/ha), which was statistically superior to remaining graded doses of fertilizer application. On the contrary, significantly the lowest plant height of $16.48 \mathrm{~cm}$, number of leaves (14.50), leaf area $\left(2945.16 \mathrm{~cm}^{2}\right)$, LAI (1.96), diameter of head $(12.66 \mathrm{~cm})$, fresh weight of head $(832.31$ g) and head yield (485.93 q/ha) was obtained with $75 \%$ RDF $\left(\mathrm{F}_{3}\right)$. The increase in head yield with increasing fertilizer levels up to $125 \%$ RDF could be attributed to increase in leaf size and leaf area which results into more production of carbohydrate by photosynthesis, increased assimilate production and ultimate allocation to the sink i.e. head that increased the size and weight of head and enhanced head yield (Kumar and Sahu, 2013).

The interaction effects between irrigation and fertilizer management showed that greatest plant height $(18.96 \mathrm{~cm})$, maximum number of leaves (15.63), leaf area per plant (3052.67 $\mathrm{cm}^{2}$ ), LAI (2.04), diameter of head (13.45 $\mathrm{cm})$, fresh weight of head $(980.21 \mathrm{~g})$ and head yield (586.34 q/ha) was found with the treatment combination of drip irrigation at 1.0 $\mathrm{ET}_{0}$ complemented with $125 \%$ RDF $\left(\mathrm{I}_{1} \mathrm{~F}_{1}\right)$ which was on parity with the treatment couplings of drip irrigation at $1.0 \mathrm{ET}_{0}$ with $100 \% \operatorname{RDF}\left(\mathrm{I}_{1} \mathrm{~F}_{2}\right)$, drip irrigation at $0.8 \mathrm{ET}_{0}$ with $125 \%$ RDF $\left(\mathrm{I}_{2} \mathrm{~F}_{1}\right)$ and drip irrigation at $0.8 \mathrm{ET}_{0}$ with $100 \% \mathrm{RDF}\left(\mathrm{I}_{2} \mathrm{~F}_{2}\right)$. The higher head yield and yield accessories with optimum to moderate deficit drip irrigation schedules (1.0 to $0.8 \mathrm{ET}_{0}$ ) in supplemented with 125 to $100 \%$ RDF might be due to adequate availability of soil water and fertilizer nutrients in the root zone throughout the growth period and their utilization for proper plant nourishment. Significantly the smallest plant height $(15.22 \mathrm{~cm})$, lowest number of leaves (13.93), leaf area per plant $\left(2822.35 \mathrm{~cm}^{2}\right)$, LAI (1.88), diameter of head $(12.28 \mathrm{~cm})$, fresh weight of head $(723.62 \mathrm{~g})$ and minimum head yield (414.54 q/ha) was observed with the treatment combination of surface irrigation with $75 \% \operatorname{RDF}\left(\mathrm{I}_{4} \mathrm{~F}_{3}\right)$. This might be due to frequent water stress followed by low availability of nutrients owing to deep percolation loss.

\section{Seasonal crop water use and crop water use efficiency}

The amount of irrigation water applied during the cropping season by drip irrigation scheduling at $0.6,0.8$ and $1.0 \mathrm{ET}_{0}$ was 42.29 , 56.39 and $70.49 \mathrm{~mm}$, respectively; while it was $120 \mathrm{~mm}$ for surface irrigation (Table 4). The effective rainfall was $59.21 \mathrm{~mm}$ for drip and $67.34 \mathrm{~mm}$ for surface irrigation. The soil profile water contribution ranged from 14.38 to $18.75 \mathrm{~mm}$. Thus, the calculated seasonal crop water use or actual crop evapotranspiration (ETa) was 116.24, 130.15 and $144.08 \mathrm{~mm}$ for drip irrigation schedule at 0.6, 0.8 and $1.0 \mathrm{ET}_{0}$, respectively and the respective value for surface irrigation was $206.09 \mathrm{~mm}$. The results revealed that maximum crop water use efficiency (435.33 $\mathrm{kg} / \mathrm{ha}-\mathrm{mm}$ ) was recorded with higher deficit drip irrigation at $0.6 \mathrm{ET}_{0}\left(\mathrm{I}_{3}\right)$ followed by that of moderate deficit drip irrigation at $0.8 \mathrm{ET}_{0}$ $\left(\mathrm{I}_{2}\right)$ as $419.69 \mathrm{~kg} / \mathrm{ha}-\mathrm{mm}$ and optimal drip 
irrigation at $1.0 \mathrm{ET}_{0}\left(\mathrm{I}_{1}\right)$ as $386.43 \mathrm{~kg} / \mathrm{ha}-\mathrm{mm}$, respectively; whereas minimum CWUE (213.94 kg/ha-mm) was accomplished with surface irrigation $\left(\mathrm{I}_{4}\right)$. Application of water through drip irrigation appreciably improved the CWUE by $80.6 \%$ for $1.0 \mathrm{ET}_{0}, 96.2 \%$ for $0.8 \mathrm{ET}_{0}$ and $103.5 \%$ for $0.6 \mathrm{ET}_{0}$ as compared with surface irrigation. The higher CWUE with drip irrigation at $0.6 \mathrm{ET}_{0}$ might be due to proportional increase in yield with full utilization of applied water. The lowest CWUE in surface irrigation could be ascribed to loss of water in evaporation and deep percolation due to higher amount of water applied at a time resulting in uneconomic water use for crop production. Higher CWUE in drip irrigation compared to surface irrigation was the result of precise amount of water application directly in the root zone at right time and minimization of water losses in evaporation, runoff and deep percolation (Kadam and Karthikeyan 2006; Rajurkar et al., 2012).

The obtained results are in accordance with Punamhoro et al., (2003) who reported that increase in WUE in drip system over furrow irrigation was mainly due to the controlled water release near the crop root zone. Similar findings have also been observed by Sharma et al., (2012) that maximum WUE was in drip irrigation at $60 \%$ ETc and the minimum WUE in the conventional irrigation system. Likewise, $125 \%$ RDF $\left(\mathrm{F}_{1}\right)$ recorded higher CWUE (359.55 kg/ha-mm) followed by $100 \% \mathrm{RDF}\left(\mathrm{F}_{2}\right)$ as $344.95 \mathrm{~kg} / \mathrm{ha}-\mathrm{mm}$ and $75 \%$ RDF $\left(\mathrm{F}_{3}\right)$ as $326.31 \mathrm{~kg} / \mathrm{ha}-\mathrm{mm}$. This implied that addition of graded doses of fertilizers had additional advantage of using applied irrigation water more efficiently in increasing yield.

The interaction effects between irrigation and fertilization indicated that higher deficit drip irrigation at $0.6 \mathrm{ET}_{0}$ along with $125 \% \mathrm{RDF}$ $\left(\mathrm{I}_{3} \mathrm{~F}_{1}\right)$ recorded the highest CWUE (445.04 $\mathrm{kg} / \mathrm{ha}-\mathrm{mm}$ ) followed by moderate deficit drip irrigation at $0.8 \mathrm{ET}_{0}$ with $125 \% \mathrm{RDF}\left(\mathrm{I}_{2} \mathrm{~F}_{1}\right)$ as $443.74 \mathrm{~kg} / \mathrm{ha}-\mathrm{mm}$. The lowest CWUE $(201.44$ $\mathrm{kg} / \mathrm{ha}-\mathrm{mm}$ ) was displayed by surface irrigation complemented with $75 \%$ RDF $\left(\mathrm{I}_{4} \mathrm{~F}_{3}\right)$. The reason for maximum CWUE in $\mathrm{I}_{3} \mathrm{~F}_{1}$ and $\mathrm{I}_{2} \mathrm{~F}_{1}$ as compared to $\mathrm{I}_{1} \mathrm{~F}_{1}$ might be attributed to lesser water use for yield maximization. Other reason could be due to the relatively higher availability of nutrients and soil water at low tensions with reduced evaporation and leaching of water and nutrients.

\section{Land and water utilization under drip irrigation}

The data on water saving and additional area likely to be cultivated due to saving of water through gravity drip irrigation system is furnished in Table 4. The results pointed out that the higher deficit drip irrigation at 0.6 $\mathrm{ET}_{0}$ saved about $64.76 \%$ water as compared with surface irrigation, which could cover $77.3 \%$ of additional area for cultivation under drip irrigation at $0.6 \mathrm{ET}_{0}$. Similarly, moderate deficit drip irrigation at $0.8 \mathrm{ET}_{0}$ could save as much as $53.01 \%$ water in comparison with surface irrigation.

On utilizing this saved water, it was possible to irrigate an additional $58.35 \%$ area under drip irrigation at $0.8 \mathrm{ET}_{0}$. Likewise, optimum drip irrigation at $1.0 \mathrm{ET}_{0}$ was found to save about $41.26 \%$ water as compared with surface irrigation which could bring an additional 43.04\% area under drip irrigated crop at 0.8 $\mathrm{ET}_{0}$.

\section{Water-yield production function}

The relationships between yield and actual crop evapotranspiration (ETa) and amount of irrigation water applied (I) were determined through non-linear regression analysis. Cabbage head yield was taken as dependent 
variable and plotted against ETa and I independently to derive mathematical functions (Fig. 1). A second degree polynomial equation was best fitted to the data of yield (y) and ETa and I. The predicted regression equations are as follows,

Relationship between ETa and y,

$\mathrm{y}=-0.0036 \mathrm{ETa}^{2}+0.9405 \mathrm{ETa}-4.9274$

$\left(\mathrm{R}^{2}=0.9998\right)$.

Relationship between I and y,

$\mathrm{y}=-0.0054 \mathrm{I}^{2}+0.7916 \mathrm{I}+26.899\left(\mathrm{R}^{2}=\right.$ $0.9986)$
The coefficients of determination $\left(\mathrm{R}^{2}\right)$ values were nearly unity in both equations and were statistically highly significant. In these model approaches, all irrigation treatments under drip and surface irrigation were taken into consideration for projecting the head yield. In the graphs, the linear effects indicated that increase in yield was proportional to the increment of ETa and I, while the quadratic effects showed the marked decline in yield with increasing ETa and I. The relationships can successfully be employed for forecasting the yield under variable ETa and I value. The predicted highest head yield of $55.91 \mathrm{t} / \mathrm{ha}$ was obtained with ETa at $128 \mathrm{~mm}$ and I at $73 \mathrm{~mm}$.

Table.1 Mean monthly weather parameters during December 2019 to March 2020

\begin{tabular}{|c|c|c|c|c|c|c|c|c|}
\hline \multirow[t]{2}{*}{ Period } & \multicolumn{2}{|c|}{$\begin{array}{c}\text { Temperature } \\
\left({ }^{0} \mathrm{C}\right)\end{array}$} & \multirow[t]{2}{*}{$\begin{array}{c}\text { Open pan } \\
\text { evaporation } \\
\text { (mm/day) }\end{array}$} & \multicolumn{2}{|c|}{$\begin{array}{c}\text { Relative } \\
\text { humidity } \\
(\%)\end{array}$} & \multirow[t]{2}{*}{$\begin{array}{c}\text { Wind } \\
\text { speed } \\
\text { (kmph) }\end{array}$} & \multirow[t]{2}{*}{$\begin{array}{c}\text { Sunshine } \\
\text { (hour) }\end{array}$} & \multirow[t]{2}{*}{$\begin{array}{c}\text { Rainfall } \\
\text { (mm) }\end{array}$} \\
\hline & $\operatorname{Max}$ & Min & & Max & Min & & & \\
\hline December & 23.4 & 12.9 & 0.95 & 91.9 & 61.5 & 0.25 & 5.9 & 20.4 \\
\hline January & 23.4 & 11.3 & 0.90 & 92.8 & 61.6 & 0.01 & 6.6 & 11.0 \\
\hline February & 26.8 & 12.5 & 1.54 & 89.4 & 47.8 & 0.02 & 6.6 & 2.9 \\
\hline March & 31.9 & 18.8 & 3.11 & 89.5 & 49.3 & 0.50 & 7.4 & 74.7 \\
\hline
\end{tabular}

Table.2 Pan evaporation (PE), reference evapotranspiration $\left(\mathrm{ET}_{0}\right)$ and crop evapotranspiration (ETc) of cabbage at different days after planting (DAP)

\begin{tabular}{|c|c|c|c|c|}
\hline DAP & PE $(\mathbf{m m})$ & ET $_{\mathbf{0}}(\mathbf{m m})$ & ETc $(\mathbf{m m})$ & Daily ETc $(\mathbf{m m} / \mathbf{d a y})$ \\
\hline $\mathbf{0 1 - 0 6}$ & 6.4 & 4.80 & 3.36 & 0.56 \\
\hline $\mathbf{0 7 - 1 6}$ & 7.5 & 5.63 & 3.94 & 0.39 \\
\hline $\mathbf{1 7 - 2 6}$ & 11.4 & 8.55 & 5.99 & 0.60 \\
\hline $\mathbf{2 7 - 3 6}$ & 16.5 & 12.38 & 12.99 & 1.30 \\
\hline $\mathbf{3 7 - 4 6}$ & 15.4 & 11.55 & 12.13 & 1.21 \\
\hline $\mathbf{4 7 - 5 6}$ & 19.8 & 14.85 & 15.59 & 1.56 \\
\hline $\mathbf{5 7 - 6 6}$ & 20.6 & 15.45 & 16.22 & 1.62 \\
\hline $\mathbf{6 7 - 7 6}$ & 24.1 & 18.08 & 17.17 & 1.72 \\
\hline $\mathbf{7 7 - 8 6}$ & 32.6 & 24.45 & 23.23 & 2.32 \\
\hline $\mathbf{8 7 - 9 4}$ & 26.8 & 20.10 & 19.10 & 2.39 \\
\hline Total & $\mathbf{1 8 1 . 1 0}$ & $\mathbf{1 3 5 . 8 3}$ & $\mathbf{1 2 9 . 7 1}$ & $\mathbf{1 . 3 8}$ \\
\hline
\end{tabular}


Table.3 Effect of different levels of irrigation, fertilization and their interactions on growth, yield constituents and fresh head yield of cabbage

\begin{tabular}{|c|c|c|c|c|c|c|c|}
\hline Treatment & $\begin{array}{c}\text { Plant } \\
\text { height } \\
(\mathrm{cm})\end{array}$ & $\begin{array}{c}\text { Number } \\
\text { of open } \\
\text { leaves }\end{array}$ & $\begin{array}{l}\text { Leaf area/ } \\
\text { plant }\left(\mathrm{cm}^{2}\right)\end{array}$ & $\begin{array}{l}\text { Leaf } \\
\text { area } \\
\text { index }\end{array}$ & $\begin{array}{l}\text { Diameter } \\
\text { of head } \\
(\mathbf{c m})\end{array}$ & $\begin{array}{c}\text { Fresh } \\
\text { weight of } \\
\text { head (g) }\end{array}$ & $\begin{array}{c}\text { Yield of } \\
\text { head } \\
\text { (q/ha) }\end{array}$ \\
\hline \multicolumn{8}{|l|}{ Irrigation (I) } \\
\hline $\mathbf{I}_{1}$ & 18.17 & 15.34 & 3031.32 & 2.02 & 13.22 & 951.66 & 556.78 \\
\hline $\mathbf{I}_{2}$ & 17.98 & 15.17 & 3016.43 & 2.01 & 13.12 & 937.10 & 546.21 \\
\hline $\mathbf{I}_{3}$ & 16.78 & 14.46 & 2986.86 & 1.99 & 12.75 & 819.37 & 506.03 \\
\hline $\mathbf{I}_{4}$ & 15.97 & 14.25 & 2852.48 & 1.90 & 12.39 & 770.07 & 440.90 \\
\hline SEm \pm & 0.09 & 0.05 & 6.68 & 0.005 & 0.04 & 7.09 & 3.55 \\
\hline CD (0.05) & 0.32 & 0.19 & 23.18 & 0.016 & 0.14 & 24.52 & 12.27 \\
\hline \multicolumn{8}{|l|}{ Fertilizer (F) } \\
\hline $\mathbf{F}_{1}$ & 18.01 & 15.14 & 2998.28 & 2.00 & 13.07 & 899.63 & 537.27 \\
\hline $\mathbf{F}_{2}$ & 17.19 & 14.78 & 2971.88 & 1.98 & 12.89 & 876.70 & 514.25 \\
\hline $\mathbf{F}_{3}$ & 16.48 & 14.50 & 2945.16 & 1.96 & 12.66 & 832.31 & 485.93 \\
\hline SEm \pm & 0.134 & 0.074 & 0.33 & 0.007 & 0.054 & 9.05 & 6.95 \\
\hline CD (0.05) & 0.47 & 0.26 & 29.15 & 0.024 & 0.19 & 31.68 & 24.32 \\
\hline \multicolumn{8}{|c|}{ Interaction $(\mathbf{I} \times \mathbf{F})$} \\
\hline $\mathbf{I}_{1} \mathbf{F}_{1}$ & 18.96 & 15.63 & 3052.67 & 2.04 & 13.45 & 980.21 & 586.34 \\
\hline $\mathbf{I}_{1} \mathbf{F}_{2}$ & 18.24 & 15.32 & 3031.86 & 2.02 & 13.24 & 958.42 & 561.83 \\
\hline $\mathbf{I}_{\mathbf{1}} \mathbf{F}_{\mathbf{3}}$ & 17.32 & 15.06 & 3009.42 & 2.01 & 12.97 & 916.34 & 522.16 \\
\hline $\mathbf{I}_{2} \mathbf{F}_{1}$ & 18.68 & 15.48 & 3041.58 & 2.03 & 13.32 & 965.87 & 578.72 \\
\hline $\mathbf{I}_{2} \mathbf{F}_{2}$ & 18.10 & 15.16 & 3020.38 & 2.01 & 13.18 & 946.68 & 547.36 \\
\hline $\mathbf{I}_{2} \mathbf{F}_{3}$ & 17.16 & 14.87 & 2987.34 & 1.99 & 12.86 & 898.74 & 512.56 \\
\hline $\mathbf{I}_{3} \mathbf{F}_{1}$ & 17.44 & 14.82 & 3012.26 & 2.01 & 12.96 & 848.22 & 518.38 \\
\hline $\mathbf{I}_{3} \mathbf{F}_{2}$ & 16.68 & 14.42 & 2986.78 & 1.99 & 12.78 & 819.36 & 505.24 \\
\hline $\mathbf{I}_{3} \mathbf{F}_{3}$ & 16.22 & 14.12 & 2961.53 & 1.97 & 12.52 & 790.54 & 494.46 \\
\hline $\mathbf{I}_{4} \mathbf{F}_{1}$ & 16.96 & 14.61 & 2886.62 & 1.92 & 12.53 & 804.23 & 465.62 \\
\hline $\mathbf{I}_{4} \mathbf{F}_{2}$ & 15.74 & 14.22 & 2848.48 & 1.90 & 12.36 & 782.35 & 442.55 \\
\hline $\mathbf{I}_{4} \mathbf{F}_{3}$ & 15.22 & 13.93 & 2822.35 & 1.88 & 12.28 & 723.62 & 414.54 \\
\hline SEm \pm & 0.23 & 0.14 & 0.13 & 0.10 & 0.11 & 15.96 & 13.87 \\
\hline CD $(0.05)$ & 0.68 & 0.41 & 0.37 & 0.029 & 0.32 & 47.54 & 41.34 \\
\hline
\end{tabular}

$\mathrm{I}_{1}$ : gravity drip irrigation at $1.0 \mathrm{ET}_{0}, \mathrm{I}_{2}$ : gravity drip irrigation at $0.8 \mathrm{ET}_{0}, \mathrm{I}_{3}$ : gravity drip irrigation at $0.6 \mathrm{ET}_{0}, \mathrm{I}_{4}$ : surface irrigation at $40 \mathrm{~mm}$ depth; $\mathrm{F}_{1}: 125 \%$ recommended dose of fertilizer (RDF), $\mathrm{F}_{2}: 100 \% \mathrm{RDF}, \mathrm{F}_{3}: 75 \% \mathrm{RDF}$ 
Table.4 Water balance component and seasonal crop water use or, actual crop evapotranspiration (ETa) for cabbage

\begin{tabular}{|c|c|c|c|c|c|c|c|}
\hline Treatment & $\begin{array}{c}\text { Profile } \\
\text { contribution } \\
(\mathbf{m m})\end{array}$ & $\begin{array}{c}\text { Effective } \\
\text { rainfall } \\
(\mathbf{m m})\end{array}$ & $\begin{array}{l}\text { Irrigation } \\
\quad(\mathbf{m m})\end{array}$ & $\begin{array}{c}\text { ETa } \\
(\mathbf{m m})\end{array}$ & $\begin{array}{c}\text { CWUE } \\
\text { (kg/ha- } \\
\text { mm) }\end{array}$ & $\begin{array}{c}\text { Water } \\
\text { saving } \\
(\%)\end{array}$ & $\begin{array}{c}\text { Additional } \\
\text { area under } \\
\text { drip }(\%)\end{array}$ \\
\hline \multicolumn{8}{|c|}{ Irrigation (I) } \\
\hline $\mathbf{I}_{1}$ & 14.38 & 59.21 & 70.49 & 144.08 & 386.43 & 41.26 & 43.04 \\
\hline $\mathbf{I}_{2}$ & 14.55 & 59.21 & 56.39 & 130.15 & 419.69 & 53.01 & 58.35 \\
\hline $\mathbf{I}_{3}$ & 14.74 & 59.21 & 42.29 & 116.24 & 435.33 & 64.76 & 77.30 \\
\hline $\mathbf{I}_{4}$ & 18.75 & 67.34 & 120.00 & 206.09 & 213.94 & - & - \\
\hline \multicolumn{8}{|c|}{ Fertilizer (F) } \\
\hline $\mathbf{F}_{1}$ & 15.89 & 61.24 & 72.29 & 149.43 & 359.55 & - & \\
\hline $\mathbf{F}_{2}$ & 15.54 & 61.24 & 72.29 & 149.08 & 344.95 & - & \\
\hline $\mathbf{F}_{3}$ & 15.38 & 61.24 & 72.29 & 148.92 & 326.31 & - & \\
\hline \multicolumn{8}{|c|}{ Interaction $(\mathbf{I} \times \mathbf{F})$} \\
\hline $\mathbf{I}_{1} \mathbf{F}_{1}$ & 14.65 & 59.21 & 70.49 & 144.35 & 406.19 & - & \\
\hline $\mathbf{I}_{1} \mathbf{F}_{2}$ & 14.32 & 59.21 & 70.49 & 144.02 & 390.11 & - & \\
\hline $\mathbf{I}_{1} \mathbf{F}_{3}$ & 14.18 & 59.21 & 70.49 & 143.88 & 362.91 & - & \\
\hline $\mathbf{I}_{2} \mathbf{F}_{1}$ & 14.82 & 59.21 & 56.39 & 130.42 & 443.74 & - & \\
\hline $\mathbf{I}_{2} \mathbf{F}_{2}$ & 14.45 & 59.21 & 56.39 & 130.05 & 420.88 & - & \\
\hline $\mathbf{I}_{2} \mathbf{F}_{3}$ & 14.37 & 59.21 & 56.39 & 129.97 & 394.37 & - & \\
\hline $\mathbf{I}_{3} \mathbf{F}_{1}$ & 14.98 & 59.21 & 42.29 & 116.48 & 445.04 & - & \\
\hline $\mathbf{I}_{3} \mathbf{F}_{2}$ & 14.73 & 59.21 & 42.29 & 116.23 & 434.69 & - & \\
\hline $\mathbf{I}_{3} \mathbf{F}_{3}$ & 14.52 & 59.21 & 42.29 & 116.02 & 426.19 & - & \\
\hline $\mathbf{I}_{4} \mathbf{F}_{1}$ & 19.12 & 67.34 & 120 & 206.46 & 225.53 & - & \\
\hline $\mathbf{I}_{4} \mathbf{F}_{2}$ & 18.67 & 67.34 & 120 & 206.01 & 214.82 & - & \\
\hline $\mathbf{I}_{\mathbf{4}} \mathbf{F}_{3}$ & 18.45 & 67.34 & 120 & 185.79 & 201.44 & - & \\
\hline
\end{tabular}

$\mathrm{I}_{1}$ : gravity drip irrigation at $1.0 \mathrm{ET}_{0}, \mathrm{I}_{2}$ : gravity drip irrigation at $0.8 \mathrm{ET}_{0}, \mathrm{I}_{3}$ : gravity drip irrigation at $0.6 \mathrm{ET}_{0}, \mathrm{I}_{4}$ : surface irrigation at $40 \mathrm{~mm}$ depth; $\mathrm{F}_{1}: 125 \%$ recommended dose of fertilizer (RDF), $\mathrm{F}_{2}: 100 \% \mathrm{RDF}, \mathrm{F}_{3}: 75 \% \mathrm{RDF}$

Table.5 Fertilizer use efficiency (FUE) under different of irrigations and fertilizers for cabbage

\begin{tabular}{|c|c|c|c|}
\hline Treatment & $\begin{array}{c}\text { Amount of fertilizer } \\
\text { applied (kg/ha) }\end{array}$ & $\begin{array}{c}\text { Head yield } \\
\text { (kg/ha) }\end{array}$ & $\begin{array}{c}\text { FUE } \\
\text { (kg/kg of nutrient) }\end{array}$ \\
\hline $\mathbf{I}_{\mathbf{1}} \mathbf{F}_{\mathbf{1}}$ & 381.25 & 58634 & 153.79 \\
\hline $\mathbf{I}_{\mathbf{1}} \mathbf{F}_{\mathbf{2}}$ & 305.00 & 56183 & 184.21 \\
\hline $\mathbf{I}_{\mathbf{1}} \mathbf{F}_{\mathbf{3}}$ & 228.75 & 52216 & 228.27 \\
\hline $\mathbf{I}_{\mathbf{2}} \mathbf{F}_{\mathbf{1}}$ & 381.25 & 57872 & 151.80 \\
\hline $\mathbf{I}_{\mathbf{2}} \mathbf{F}_{\mathbf{2}}$ & 305.00 & 54736 & 179.46 \\
\hline $\mathbf{I}_{\mathbf{2}} \mathbf{F}_{\mathbf{3}}$ & 228.75 & 51256 & 224.07 \\
\hline $\mathbf{I}_{\mathbf{3}} \mathbf{F}_{\mathbf{1}}$ & 381.25 & 51838 & 135.97 \\
\hline $\mathbf{I}_{\mathbf{3}} \mathbf{F}_{\mathbf{2}}$ & 305.00 & 50524 & 165.65 \\
\hline $\mathbf{I}_{\mathbf{3}} \mathbf{F}_{\mathbf{3}}$ & 228.75 & 49446 & 216.16 \\
\hline $\mathbf{I}_{\mathbf{4}} \mathbf{F}_{\mathbf{1}}$ & 381.25 & 46562 & 122.13 \\
\hline $\mathbf{I}_{\mathbf{4}} \mathbf{F}_{\mathbf{2}}$ & 305.00 & 44255 & 145.10 \\
\hline $\mathbf{I}_{\mathbf{4}} \mathbf{F}_{\mathbf{3}}$ & 228.75 & 41454 & 181.22 \\
\hline
\end{tabular}

$\mathrm{I}_{1}$ : gravity drip irrigation at $1.0 \mathrm{ET}_{0}, \mathrm{I}_{2}$ : gravity drip irrigation at $0.8 \mathrm{ET}_{0}, \mathrm{I}_{3}$ : gravity drip irrigation at $0.6 \mathrm{ET}_{0}, \mathrm{I}_{4}$ : surface irrigation at $40 \mathrm{~mm}$ depth; $\mathrm{F}_{1}: 125 \%$ recommended dose of fertilizer $(\mathrm{RDF}), \mathrm{F}_{2}: 100 \% \mathrm{RDF}, \mathrm{F}_{3}: 75 \% \mathrm{RDF}$ 
Table.6 Relationship between decrease in relative water use and decrease in relative yield for cabbage

\begin{tabular}{|c|c|c|c|c|c|c|c|}
\hline $\begin{array}{c}\text { Drip } \\
\text { irrigation }\end{array}$ & $\begin{array}{c}\mathbf{E T a} \\
(\mathbf{m m})\end{array}$ & $\begin{array}{c}\mathbf{E T m} \\
\mathbf{( m m})\end{array}$ & $(\mathbf{1 - E T a} / \mathbf{E T m})$ & $\begin{array}{c}\mathbf{Y a} \\
(\mathbf{t} / \mathbf{h a})\end{array}$ & $\begin{array}{c}\mathbf{Y m} \\
\mathbf{( t / h a})\end{array}$ & $\mathbf{( 1 - Y a / Y m )}$ & $\mathbf{K y}$ \\
\hline $\mathbf{I}_{\mathbf{1}}$ & 144.08 & 144.08 & 0 & 55.678 & 55.678 & 0 & 0 \\
\hline $\mathbf{I}_{\mathbf{2}}$ & 130.15 & 144.08 & 0.0967 & 54.621 & 55.678 & 0.0190 & 0.196 \\
\hline $\mathbf{I}_{\mathbf{3}}$ & 116.24 & 144.08 & 0.1932 & 50.603 & 55.678 & 0.0911 & 0.472 \\
\hline
\end{tabular}

$\mathrm{I}_{1}$ : drip irrigation at $1.0 \mathrm{ET}_{0}, \mathrm{I}_{2}$ : drip irrigation at $0.8 \mathrm{ET}_{0}, \mathrm{I}_{3}$ : drip irrigation at $0.6 \mathrm{ET}_{0}$

Fig.1 Relationship between cabbage head yield and (a) irrigation water and (b) actual crop evapotranspiration

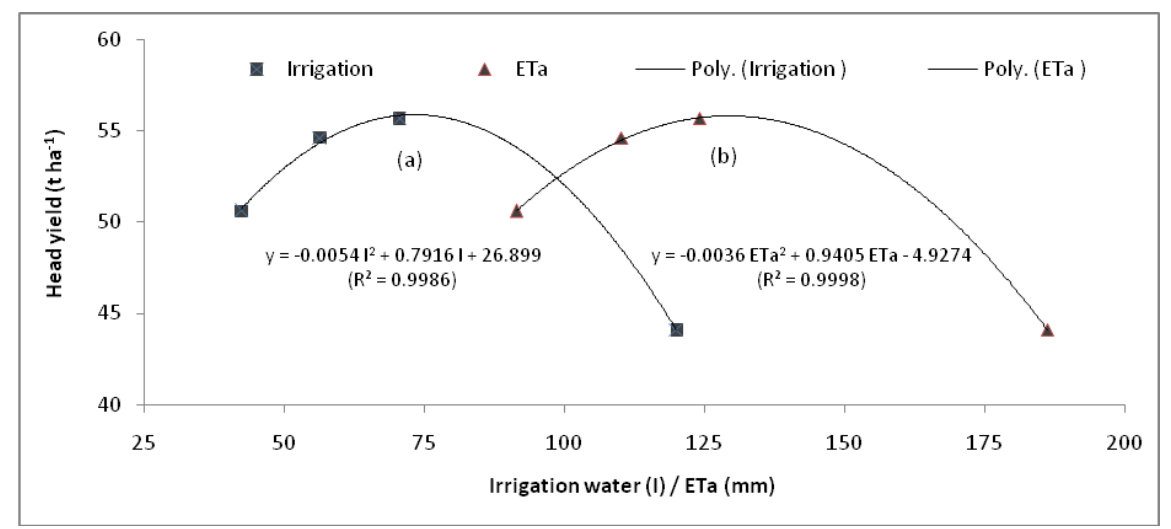

Fig.2 Relationship between the relative yield deficit and relative evapotranspiration deficit for cabbage throughout the total growing period

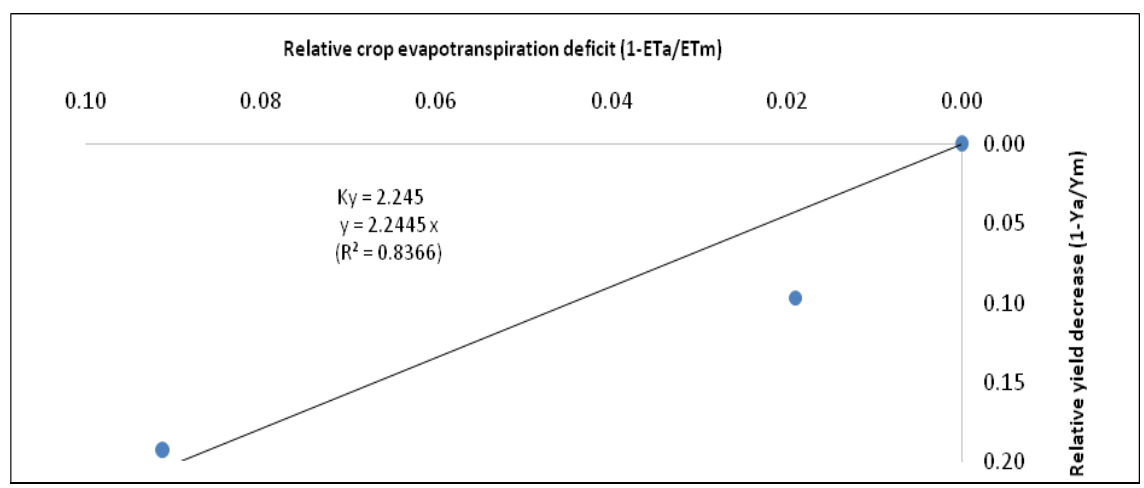

The projected yield reductions by the imposed irrigation treatment for surface irrigation, drip irrigation at $0.6,0.8$ and 1.0 of $\mathrm{ET}_{0}$ were 21.1, $9.5,2.3$ and $0.4 \%$, respectively. The drastic reduction in yield was observed with surface irrigation followed by higher deficit drip irrigation at 0.6 ETc which might have resulted more negative effect on crop through higher soil water excess and deficit, respectively. Even the optimum drip irrigation schedule at $1.0 \mathrm{ET}_{0}$ applying relatively higher amount of water $(70.49 \mathrm{~mm})$ had little adverse effect in discouraging yield. These results focus an interesting point for cabbage growers from irrigation management point of view. In the present set of climatic conditions, 
the amount of irrigation water at $73 \mathrm{~mm}$ or actual crop evapotranspiration at $128 \mathrm{~mm}$ could be used as a good platform for cabbage growers in the Indo-Gangetic plains or similar agro-climatic regions for obtaining maximum head yield and optimum utilization of irrigation water resources. The equations can also serve as suitable guideline to yield potential allocation decision related to variable irrigation water supply.

\section{Fertilizer use efficiency (FUE)}

Fertilizer use efficiency (FUE) is the increase in yield ( $\mathrm{kg}$ yield/ha) per unit use of applied fertilizer nutrient (kg/ha). The results furnished in Table 5 showed that FUE at each irrigation level increased consistently with concomitant decrease in nutrients and vice versa.

Maximum FUE of $228.27 \mathrm{~kg} / \mathrm{kg}$ of nutrient applied was obtained with optimum drip irrigation at $1.0 \mathrm{ET}_{0}$ with $75 \% \mathrm{RDF}\left(\mathrm{I}_{1} \mathrm{~F}_{3}\right)$ followed by moderate deficit drip irrigation at $0.8 \mathrm{ET}_{0}$ with $75 \% \mathrm{RDF}\left(\mathrm{I}_{2} \mathrm{~F}_{3}\right)$ as $224.07 \mathrm{~kg} / \mathrm{kg}$ of nutrient applied; whereas minimum FUE of $122.13 \mathrm{~kg} / \mathrm{kg}$ of nutrient applied was accomplished with surface irrigation coupling with $125 \%$ RDF $\left(\mathrm{I}_{4} \mathrm{~F}_{1}\right)$.

Higher FUE in the treatment combinations $\mathrm{I}_{1} \mathrm{~F}_{3}$ and $\mathrm{I}_{2} \mathrm{~F}_{3}$ might be attributed to the efficient utilization of fertilizer nutrients at optimum to moderate deficit irrigation regime imposed by drip irrigation with precise and controlled water application, thereby mitigating the crop water demand all along the crop growth stages and also checking the nutrients loss through runoff or deep percolation. However, in surface irrigated system the FUE was notably low which ascribed to non-uniform water and nutrients distribution around the root zone periphery and runoff and leaching loss of water and nutrients at higher extent.

\section{Crop yield response factor $(\mathrm{Ky})$}

The response of cabbage yield to crop water use during growing season is quantified through the yield response factor (Ky) and was computed by the Stewart's model (Stewart et al., 1977) as $\mathrm{Ky}=\frac{1-\mathrm{Ya} / \mathrm{Ym}}{1-\mathrm{ETa} / \mathrm{ETm}}$

Where, Ya is the actual head yield (t/ha), Ym is the maximum head yield ( $\mathrm{t} / \mathrm{ha})$, ETa is the actual evapotranspiration $(\mathrm{mm})$ and ETm is the maximum evapotranspiration $(\mathrm{mm})$ and $\mathrm{Ky}$ is the response factor to deficit irrigation management. Ky is the slope of the linear relationship between the reduction in relative yield and the reduction in relative evapotranspiration. It shows the response of yield with concomitant decrease in water consumption. In other words, it explains the decline in yield with respect to per unit decrease in water use. The relationship between relative yield deficit and relative evapotranspiration deficit for cabbage is furnished in Fig. 2. The seasonal yield response factor $(\mathrm{Ky})$ was found to be 2.245 with high coefficient of determination $\left(\mathrm{R}^{2}=\right.$ 0.84). The value of $\mathrm{Ky}$ increased with increase in water deficit (Table 6). Higher Ky value under higher degree of water stress under drip irrigation at $0.6 \mathrm{ET}_{0}$ indicates that the plant will have a greater yield loss when optimal crop water requirements are not replenished. This also implies a high impact of soil-water stress treatment on the cabbage yield. According to the proposition of Doorenbos and Kassam (1979) that if Ky > 1.0 , the reduction in yield is proportionally larger with decrease in water use as the test crop being shallow rooted is highly sensitive to soil water deficit. Thus maintenance of optimal soil water regime by proper irrigation scheduling based on pan evaporation replenishment using gravity fed drip irrigation system at all physiological stages of plant is very imperative. 
In conclusion based on the above results, it may be inferred that imposition of gravity fed drip irrigation at $0.8 \mathrm{ET}_{0}$ along with $100 \%$ RDF was found the best treatment combination for deriving higher yield, water and fertilizer use efficiencies and substantial water saving which likely to be beneficial to the farmers of Indo-Gangetic plains or similar agro-climatic condition.

\section{References}

Agrawal, N., Tamrakar, S.K., Tripathi, M.P. and Tiwari, R.B. 2018. Response of cabbage under different levels of irrigation and fertigation through drip. Int. J. Curr. Microbiol. App. Sci., 6: 750759.

Aiyelaagbe, I.O.O. and Ogbonnaya, F.C. 1996. Growth, fruit production and seed yield of okra (Abelmoschus esculentus L.) in response to irrigation and mulching. Research Bull., No. 18. National Horticultural Research Institute, Ibadan. pp 13.

Allen, R.G., Pereira, L.S., Raes, D. and Smith, M. 1998. Crop evapotranspiration guidelines for computing crop water requirements. Irrigation and Drainage Paper No. 56, FAO, Rome, Italy. pp 300.

Anonymous. 2019. Indian Horticulture Database, National Horticulture Board. Government of India. www.nhb.gov.in.

Brahma, S., Phookan, D.B., Kachari, M., Hazarika, T.K. and Das, K. 2010. Growth, yield and economics of broccoli under different levels of nitrogen fertigation. Indian J. Hort., 67: 279-282.

Chaudhary, M.M., Bhanvadia, A.S and Parmar, P.N. 2015. Effect of integrated nutrient management on growth, yield attributes and yield of cabbage (Brassica oleracea Var. Capitata L.) under middle Gujarat conditions. Trends Biosci., 8(8): 21642168.

Doorenbos, J. and Kassam, A.H. 1979. Yield response to water. FAO Irrigation and Drainage Paper No. 33, FAO, Rome,
Italy. pp 193.

FAO. 1974. Measurement of effective rainfall. Irrigation and Drainage Paper No, 24.

Gomez, K.A. and Gomez, A.A. 1983. Statistical Procedures for Agricultural Research $2^{\text {nd }}$ Edn., International Rice Research Institute, Los Banos, Philippines.

Gorantiwar, S.D., Pingale, L.V., Pampaltiwar, P.S., Pagar, V.N. and Saradesai, M.A. 1991. Evaluation of drip irrigation for ladies finger. Maharashtra J. Hort., 5(2): 93-97.

Hasan, M.R., Sani, M.N.H., Tahmina, E. and Uddain, J. 2018. Growth and yield responses of cabbage cultivars as influenced by organic and inorganic fertilizers. Asian Res. J. Agric., 9(3): 112.

Himanshu, S.K., Singh, A.K., Kumar, S. and Kalura, P. 2013. Response of broccolli to irrigation scheduling and methods under drip, sprinkler and surface irrigation. Int. J. Engg. Adv. Tech., 2(4): 2249-2258.

Howell, T.A. 2000. Irrigation's role in enhancing water use efficiency. In: R.G. Evans, B.L. Benham, T.P. Trooien (Eds.), Proceedings of the 4th Decennial National Irrigation Symposium, ASAE, St. Joseph, MI. pp 66-80.

Indrea, D., Apahidean, S., Apahidean, M. Măniuţiu, D. and Sima, R. 2014. Vegetable crops. Ed. Bucureşti, Romania: CERES.

Kadam, J.R. and Karthikeyan, S. 2006. Effect of soluble NPK fertilizers on the nutrient balance, water use efficiency, fertilizer use efficiency of drip system in a tomato. Int. J. Plant Sci., 1: 92-94.

Kumar, J.L.G. and Senseba, T. 2008. Yield irrigation production efficiency and economic return of broccoli (Brassica oleracea var. italica) under different irrigation method and schedules. J. Env. Res. Dev., 2(4): 513-522.

Kumar, P. and Sahu, R.L. 2013. Effect of irrigation and fertigation levels on cabbage. An Asian J. Soil Sci., 8: 270274. 
Kumar, S., Imtiyaz, M., Kumar, A., Singh, R. 2007. Response of onion (Allium cepa L.) to different levels of irrigation water. Agric. Water Mng., 89(1-2): 161-166.

Nalliah, V., Ranjan, R.S., and Kahimba, F.C. 2009. Evaluation of a plant-controlled subsurface drip irrigation system. Biosyst. Eng., 102: 313-320.

Nikzad, M., Aravinda Kumar, J.S., Anjanappa, M., Amarananjundeswara, H., Dhananjaya, B.N. and Basavaraj, G. 2020. Effect of fertigation, levels on growth and yield of cabbage (Brassica oleracea L. var. capitata). Int. J. Curr. Microbiol. App. Sci., 9(1): 1240-1247.

Panigrahi, P., Sahu, N.N. and Pradhan, S. 2011. Evaluating partial root-zone irrigation and mulching in okra (Abelmoschus esculentus L.) under a sub-humid tropical climate. J. Agric. Rural Dev. Tropics Subtropics, 112(2): 169-175.

Pattanaik, S.K., Sahu, N.N., Pradhan, P.C and Mohanty, M.K. 2003 Response of banana to drip irrigation under different irrigation designs. J. Agric. Eng., ISAE, 40(3): 29-34.

Postel, S., Polak, P., Gonzales, F. and Keller, J. 2001. Drip irrigation for small farmers. A new initiative to alleviate hunger and poverty. Water Intl., 26: 3-13.

Punamhoro, P.B.N., Chowdhary, B.M. and Kandeyang, S. 2003. Performance of different irrigation methods in okra (Abelmoschus esculentus (L.) Moench). J. Res., BAU, 15(2): 205-210.

Rajurkar, G., Patel, N. and Rajput, T.B.S. and
Varghese, C. 2012. Soil water and nitrate dynamics under drip irrigated cabbage. J. Soil Water Cons., 11(3): 196-204.

Shamshiri, M.H., Mozafari, V., Sedaghati, E. and Bagheri, V. 2011. Response of petunia plants (Petunia hybrida cv. Mix) inoculated with Glomus mosseae and Glomus intraradices to phosphorous and drought stress. J. Agr. Sci. Technol., 13: 929-942.

Sharma, S., Halder, A., Patra, S.K. and Ray, R. 2012. Effect of drip irrigation and nitrogen fertigation on water use efficiency (WUE) and cost economics of guava cv. Khaja, Prog. Hor., 44: 136141.

Simsek, M., Tonkaz, T., Kacira, M., Comiekcioglu, N. and Dogan, Z. 2005. The effects of different irrigation regimes on cucumber (Cucumbis sativus L.) yield and yield characteristics under open field conditions. Agric. Water Mng., 73: 173-191.

Stewart, J.L, Danielson, R.E., Hanks, R.J., Jackson, E.B., Hagan, R.M., Pruitt, W.O., Franklin, W.T. and Riley, J.P. 1977. Optimizing crop production through control of water and salinity levels in the soil. Utah Water Laboratory PRWG151-1, Logan 19.

Vaux, H.J. and Pruitt, W.O. 1983. Crop water production functions. Adv. Irrigation., 2: 61-97.

\section{How to cite this article:}

Souptik Sarkar, Rounak Saha and Sanmay Kumar Patra. 2020. Irrigation and Fertilizer Management on Growth, Yield, Water and Fertilizer Use Efficiencies on Cabbage in a Sandy Loam Soil. Int.J.Curr.Microbiol.App.Sci. 9(12): 64-77. doi: https://doi.org/10.20546/ijcmas.2020.912.010 